\title{
Governance Quality and Growth Performance in Sub-Sahara Africa: Dynamic Panel Systems Generalized Methods of Moments
}

\author{
Amsalu Bedemo \\ School of Policy Studies, Ethiopian Civil Service University, CMC Road, Addis Ababa, Ethiopia
}

\begin{abstract}
The objective of this paper is to examine the effect of governance quality on growth performance of Sub-Sahara African Countries. The data were obtained from World Bank database over the period 2002-2018 for a sample 22 countries. The method of dynamic panel systems generalized methods of moments (SYS-GMM) was applied to estimate the model. The overall finding reveals that governance quality plays significant role in economic growth performance of the countries. The aggregate (composite governance index) has positive significant effect, where a unit improvement in composite governance index increases economic growth (GDP) by about 3.4 percent. The disaggregated result also reveals that corruption and political stability do have negative and statistically significant effect on growth performance, whereas rule of law, voice and accountability and government effectiveness have positive significant effect on growth. The effect of regulatory quality index even if positive, it is not significant. The paper recommends consistent and strong policy interventions by respective governments in order to improve governance quality emphasizing on areas where the problems are especially serious such as problems of political stability, lack proper implementation of the rule of law and corruption control.
\end{abstract}

Keywords: Governance quality, Growth, Panel GM, Sub-Sahara-Africa,

DOI: $10.7176 / \mathrm{IAGS} / 86-01$

Publication date:September $30^{\text {th }} 2020$

\section{Introduction}

The theoretical modeling practices to understand the cross-country differences in growth performances mainly involve three waves of developments; the neoclassical growth model, the endogenous growth, and the modern growth theory. The influential neoclassical growth model by Robert Solow (1956) contended that economic growth is mainly determined by inputs of capital and labor. The model emphasized on the importance of saving and capital formation for economic growth as well as to account for empirical measures of sources of growth. Thus, according to the model differences in growth performance among countries are the results of different paths of factor accumulations that each country achieved; where the differences in factor accumulations are the result of differences in capital accumulation and saving rates. Obviously, technological progresses that are expected to contribute to increased productivity of all factors of production and that bring the entrepreneurial development were not parts of the model (Raj and Breda, 2011). Rather they are taken as exogenous that would come from outside. The main implication of this model is that domestic economic policies cannot affect the steady-state, longrun growth rate. The extension of this model by (Romer, 1986 and Lucas, 1988) emphasized on the role of incentives to affect technical progress and thereby make both physical and human capital more productive to bring steady-state growth. This again implies that domestic policies can alter a country's long-run rate of economic growth.

The second wave, a more celebrated modeling exercise, consists of endogenous growth model along with its varieties. Endogenous model is the economic growth modeling process where long-run growth is determined by forces that are internal to the economic system, particularly related to the creation and use of technological knowledge. It has endogenized the process of growth and technical progress according much emphasis to the importance of technological innovation and invention for economic growth. This model, as initiated by Romer (1990) argued that innovation causes productivity growth by creating new varieties of products. The implication is that as technology advances, it becomes more complex, and hence society must make an ever-increasing expenditure on research and development to keep innovating at the same rate as before. Thus, the way to grow rapidly is not to save a large fraction of national income but to devote a large fraction of it to innovation, research, and development tasks.

Finally, a more recent wave of the modeling practices comprises of the New Growth Theory. As elaborated above, in both of the models differences in capital accumulation and technological progress were taken as the sources of economic growth that could bring differences in growth performance across nations. But the question remains unanswered is why some countries have less human capital, physical capital, and technology and could not make wise use of their factors of production and opportunities for better performance? The answer to this question may lead us to believe that there are some other causes for growth and performance differences across countries which are basic. As indicated by Acemoglu, Johnson, and Robinson (2005), "though these theoretical traditions are still vibrant in the analysis of economic growth and have provided many insights about its mechanics, for a long time it was unable to provide a fundamental explanation for economic growth". According to these 
authors, the factors listed above; capital accumulation for neoclassical growth and technological innovation for endogenous growth models are only proximate causes of growth and do not represent the fundamental explanation of comparative growth differences among nations. This has called the importance to incorporate institutions and issues of governance as the fundamental cause of differences among countries in their growth performance as a new growth theory.

This paper, by applying the theoretical foundations of the new growth theory, will try to explore the contribution of governance quality on the economic growth performance of selected sub-Sahara Africa Countries. The main objective of the paper is to empirically examine the effect of both aggregate and individual level governance quality indicators on the economic growth of the countries. The rest of the paper is organized as follows. Section two is literature review that begins with the conceptualization of governance and went on an exhaustive review of previous empirical studies. The third section deals with data and methodology including model specification. Section four is a discussion of the finding and finally conclusion and policy implication is provided in section five.

\section{Literature Review}

\subsection{Definition and Conceptualization of Governance}

The term governance has been frequently discoursed in the fields of political science, public administration, and public economics for decades. The concept poses lots of debates about its definition, conceptualization, and measurement. Different scholars and multinational institutions defined governance in more or less similar ways. Let us see some of the most widely referred definitions and conceptualizations. According to Keping (2017) governance means exercising authority to maintain order and meet the needs of the public within a certain range. Kaufmann et al. (2010) defined governance as traditions and institutions by which authority in a country is exercised'. For de Ferranti et al. (2009), "governance describes the overall manner in which public officials and institutions acquire and exercise their authority to shape public policy and provide public goods and services".

Similarly, the definitions and conceptualizations by different multinational institutions are briefly outlined as follows. Governance is 'the exercise of economic, political and administrative authority to manage a country's affairs at all levels', which 'comprises mechanisms, processes, and institutions through which citizens and groups articulate their interests, exercise their legal rights, meet their obligations and mediate their differences'. It is 'the process by which public institutions conduct public affairs and manage public resources (UNDP, 1997). For the OECD, it is the use of political authority and exercise of control in society concerning the management of its resources for social and economic development (OECD, 1995). For World Bank governance is how public officials and institutions acquire and exercise the authority to shape public policy and provide public goods and services; it is 'the rule of the rulers', typically within a given set of rules (World Bank, 2007a; Kaufmann et. al., (2010)).

We can understand from these definitions that despite differences in words and use of language, the definitions have three main elements in common that direct towards to better understanding of the concept; the process (manner), power (authority), and management of collective affairs of a community, or society or a country. All of the details or aspects of definitions of governance suggest various criteria and standards against which the quality of governance can be assessed or measured.

The World Bank's definition of governance provided by Kaufmann et. al. (2010) is widely and practically used as a measure of Worldwide Governance Indicators in terms of six aggregate variables; voice and accountability; political stability and the absence of violence; government effectiveness; regulatory quality; the rule of law; and control of corruption (World Bank 2007b).

\subsection{Good governance and quality of governance}

The more recent debates in the area of development policy focused on the role of good governance in the economic and social development of nations. Good governance is the ability of the government to deliver quality public service in terms of stated objectives while maintaining public confidence and trust in its leadership (Yu Keping, 2017). It is the public administration process that maximizes public interest. Nowadays, there is general consensus among academicians and policymakers that good governance is critically important for the economic development of countries. This is because good governance, by promoting a more efficient market system, by creating more transparent public administration, by facilitating more productive investment and faster implementation of social and economic policies, will lead to higher economic growth (United Nations, 2005).

Good governance is practically assessed or measured based on the outcome or the result in steady of measuring it directly. It can be captured in terms of improvements in political regimes, economic management, quality and content of economic policy as well as the legal and judicial framework (Quibria, 2006). In terms of political regimes, it emphasizes on political contestability and processes, political and civil liberties, and legitimacy of the government. The perspective on economic management stresses the exercise and soundness of government authority in the management of a country's social and economic resources in transparent and accountable process. The perspective on the quality and content of economic policy has emphasized the extent to which the quality and 
content of economic policy address the country's development problems by designing, formulating as well as implementing appropriate policies. Finally, the legal and judicial perspective focuses on formal and informal institutions by defining, regulating, and mediating the interactions between the government and citizens, including the private sector and civil society (Quibria, 2006). Generally, the different perspectives of the definitions indicate that good governance remains a broad, multi-dimensional concept that lacks operational precision

Another concept related to the concept of good governance is quality of governance. Even though the term quality itself in general and governance quality, in particular, is a highly subjective concept, it is frequently used in literature to mean an improvement in certain proxy indicators of aggregate governance measures. Thus, in this paper governance quality refers to an improvement in World Governance Indicators which provides information on governance scores on six aggregate indicators (Kaufman et al., 2009). The estimate of composite indicators centered on zero and ranging from -2.5 to 2.5 or in percentile rank terms ranging from 0 (lowest) to 100 (highest) among all countries worldwide where larger positive values indicate better quality governance or higher governance performance.

To sum up, governance quality is not only about the use of powers by the government in a transparent and participatory way, but also it entails a good and trustful exercise of power by the government. Inherently, it concerns the fulfilment of the three basic tasks of government: to warranty peace and security of citizens and society as whole; to manage the public resource and the public sector in an effective and accountable way; and to promote the economic and social aims of the nation in accordance with the interest of the people.

\subsection{Quality of Governance and Economic Growth}

There is plenty of empirical literature demonstrating a positive relationship between governance quality and economic growth. The following is a brief summary of some of the studies. Abdullahi et.al. (2019) examined the impact of institutional quality on economic growth using the Generalised Method of Moments (GMM) approach on a sample of 46 sub-Saharan African countries over the period 2000-2014. The empirical result indicated that institutional quality has both a direct and indirect impact on economic growth and therefore revealed that the interaction term of has a statistically significant impact on the debt-growth relationship.

The study by Salawu, et.al (2108) on three SSA countries namely; Nigeria, Ghana, and South Africa revealed that South Africa and Ghana enjoyed better governance than Nigeria and thus found that governance impacts positively on the economic growth of South Africa and Ghana, however, governance has a negative significant impact on economic growth of Nigeria.

Similarly, Seid (2017) has examined the relation between good governance and economic growth in Ethiopia using time series analysis and found that good governance has a significant direct impact on economic growth in Ethiopia. The study by Noha and I-Ming Chiu (2016) on the impact of governance on economic growth in the Middle East and North African Countries found that good governance has a significant direct impact on growth over the time under consideration. Specifically, they observed a rise by about $2 \%$ in GDP if the Composite Governance Indicator increases by one unit.

Saima et.al (2014) conducted an empirical analysis to quantify the impact of institutions on economic growth in selected Asian economies over the period 19962012 by employing both static and dynamic panel system Generalised Method of Moments (GMM) technique with fixed effects. The results revealed that institutions indeed are important in determining the long-run economic growth in Asian economies. However, its impact on economic growth differs across Asian economies and depends on the level of economic development. The results showed that institutions are more effective in developed Asia than developing Asia, implying that different countries require a different set of institutions to promote long term economic growth.

Han, Khan, and Zhuang (2014) conducted a cross-country analysis for Developing Asian, Middle East, and North African Countries using six aggregate World Governance Indicators. Their finding indicated that countries with governance surplus are observed to grow faster than those with a deficit in governance indicators by as much as 2.5 percentage points annually. Good governance was associated with both a higher level of per capita GDP and higher rates of GDP growth over time. This suggests that good governance can also help in improving a country's economic prospects.

Bassam (2013) examined whether there exists a strong relationship between governance and growth during economic crises. The result demonstrated that the global economic crisis has had an unnoticeable influence on the relationship between governance and economic growth. However, this study found that different levels of development of nations affect the relationship between governance and growth in various ways during times of crisis.

Azmat (2011) examined whether governance matters for the economic growth of developing countries using a panel data estimation procedure for 84 low and middle-income countries. The empirical results revealed that political stability and government effectiveness are significantly positively correlated with growth. Voice and accountability and corruption are significantly negatively correlated with growth, but regulatory quality and rule of law are not significant. 
Rasha et.al (2011) explored the link between institutional quality and economic performance in 27 SubSaharan Africa (SSA) countries during the period 1984-2003. Institutional indicators of government stability, corruption, ethnic tensions, and socioeconomic conditions along with other control and policy variables, are employed in a panel data analysis. Findings showed that institutional variables assumed a key role in the process of economic development whereas the control variables display a limited effect.

Juzhong et.al.(2010) examined the role of governance and institutions in supporting growth and broadening inclusiveness with a special reference to developing Asia. The empirical analysis showed that developing Asian economies with government effectiveness, regulatory quality, and rule of law scoring above the global means in 1998 grew faster on average during 1998- 2008 than those economies scoring below the global means. There are many other studies by different scholars that showed the positive relationship between the growth performance of countries and governance improvements (Albassam, 2012a; Kaufman and Kraay, 2008; Forborn and Richter, 2005; Kaufmann and Kraay, 2002).

As observed above, although many empirical findings are confirming a strong relationship between economic growth and good governance, the direction of causality is still debatable. That is, the question of whether good governance practices lead to economic growth or economic growth leads to better governance is a questionable issue (Acemoglu, Johnson, \& Robinson, 2001; Arndt \& Oman, 2010; Dixit, 2009; Kaufman, Kraay, \& Mastruzzi, 2009). Therefore, the power and direction of the relationship between economic growth and governance have been and will continue to be the subject of disagreement among policymakers and those in academia (Acemoglu, Johnson, \& Robinson 2001; Alkire, 2010).

\section{Data and Methodology}

\subsection{Data and its Measurement}

Data for this research are extracted from the World Development Indicator and World Governance Indicators of the World Bank dataset spanning from the year 2002 to 2018 for 22 Sub-Saharan Africa countries. The main sets of explanatory variables for the analysis are the governance quality indicators and some control variables. It is palpable that if defining governance has been a challenging issue, one could expect that measuring governance will even be a more challenging task. Despite this challenge, however, international multinational institutions such as World Bank have been actively engaged in the task of measuring the quality of governance since 1996. This paper has used the World Governance Indicators (WGI) dataset which provides information on governance scores on six aggregate indicators (Kaufman et al., 2009). The definitions of indicators are provided briefly as below;

Voice and accountability capture the perception of the extent to which citizens can participate in selecting their government, having access to free media and the freedom of association as well as the press. Political stability and absence of violence measure the likelihood that the government may be destabilized by unconstitutional or violent means, including terrorism. Government effectiveness is measured by the quality of public services, the capacity of the civil service and its independence from political pressures, and the quality of policy formulation. Regulatory quality measures the ability of the government to provide sound policies and regulations that enable and promote private sector development. Rule of law captures the perception of the extent to which agents/citizens have confidence in and abides by the rules of society, including the quality of property rights, the police, and the courts, as well as the risk of crime. Finally, control of corruption is measured by the extent to which public power is exercised for private gain, including both petty and grand forms of corruption. The indicators were used by Kaufmann et al. (2010) to measure the quality of governance and also policymakers, International Organizations, and scholars applied them to evaluate countries' governance performances and its link to economic growth (Arndt \& Oman, 2010). The indicators are based on opinion and perception-based surveys of various governance measures from investment consulting firms, non-government organizations, think tank groups, governments, and multilateral agencies; and classified into six clusters (Kaufmann, Kraay, and Mastruzzi, 2003). The composite indicator for each country is constructed to yield a value-centered on zero and ranging from -2.5 to 2.5 where larger positive values indicate better quality governance or higher governance performance.

Similarly, the control variables used in the analysis are drawn from the World Bank's World Development Indicator dataset. These are PPP adjusted constant per capita GDP which is the dependent variable for this analysis. The control variables are gross fixed capital formation as a percent of GDP (a proxy for investment); trade openness measured as the ration of export and import to GDP to capture the importance of exports and imports in growth performance; foreign direct investment ( as \% GDP) to capture the role of foreign capital inflows in domestic economic growth; annual population growth rate (in percent); gross enrollment in primary education measured in percent (a proxy for education), inflation (a proxy for macroeconomic stability) and composite governance index derived from six governance indices through Principal Component Analysis (PCA). All of the variables except governance indicators are in logarithm form.

\subsection{Model Specification and Estimation}

First, as a part of the methodology, the Principal Component Analysis (PCA) was employed to generate a 
composite index of governance. PCA delivers the orthogonal linear transformation of high dimension governance indicators into a low dimension composite indexes (Batuo, Mlambo, and Asongu 2018; Noha and I-Ming Chiu, 2016). The composite governance index thus obtained through this method is used as an explanatory variable in the next regression. The Panel system Dynamic Generalized Method of Moments (GMM) was employed to examine the effect of governance quality and other control variables on growth performance across selected countries and over time. GMM is superior over fixed effect and random effect models in that it could capture both country-specific unobserved heterogeneities as well as possible endogeneity in regressors. Dynamism is introduced into the model by incorporating the one year lagged value of the dependent variable as an explanatory variable which allows for partial adjustment of the variable to its long-run equilibrium (Baltagi et al., 2008).

Since static linear regression approaches that apply OLS cannot eliminate the unobservable country-specific effects and possible endogeneity problems in the regressors, most empirical studies use dynamic panel model specifications. The generalized methods of moments (GMM) estimators by Blundell and Bond (1998) is by far better than other panel data estimators as it controls for both time and country-specific effects while using appropriate lags of the regressors as instruments to address the endogeneity problem.

The model to be estimated can be specified as:

$Y_{i t}=\alpha_{i}+\beta Y_{i t-1}+\gamma G_{i t}+\rho X_{i t}+\eta_{i}+\mu_{t}+\varepsilon_{i t}$

Where $Y_{i t}$ is the log real GDP per capita in the country $i$ at time $t ; G_{i t}$ represents the governance indicators, $\mathrm{X}_{\mathrm{it}}$ refers to the control variables, $\mathrm{t}$ stands for the period, and $\mathrm{i}$ country. The variable, $\eta_{\mathrm{i}}$, is meant to capture unobserved country-specific effect, $\mu_{t}$ is a dummy to account for time-specific effect and $\varepsilon_{i t}$ is the error term.

Although the model in the equation above can be estimated using fixed and/or random effect estimation, both approaches cannot capture unobservable country specifics effects and cannot deal with the possible endogeneity problems in the regressors. As a solution to this problem, Arellano and Bond (1991) proposed the first difference equation to eliminate the country-specific effect, but the approach again will introduce another endogeneity bias resulting from the introduction of first-difference of the dependent variable as a regressor. Moreover, as argued by Blundell and Bond (1998), since the difference-GMM suffers from weak instruments due to the high persistence of data (resulting from differencing), they proposed the systems based GMM estimator (SYS-GMM). This is preferable to other methods because it is more efficient in handling the problem of weak instruments as well as dealing with issues of unobserved effects and endogeneity problems. Furthermore, it combines both the equations in levels and first difference as a system, to utilize a larger number of instruments.

Therefore, in this work, we estimate the coefficients of equation (1) using sys-GMM with two-step GMM which is asymptotically more efficient than the one-step following the initial work of Blundell and Bond (1998) and a subsequent application by researchers.

\section{Findings and Discussions}

\subsection{Descriptive statistics and Principal Component Analysis}

The dynamic panel systems Generalized Methods of Moments (GMM) was estimated to examine the effect of governance quality on the growth performance of selected Sub-Saharan countries. To make descriptive data more elaborative, 16 years average values of control variables in Annex 1 and for governance indicators in annex 2 are provided for 22 countries are provided. Moreover, the descriptive statstics of the overall data used is provided in annex table 3. As can be seen from Annex 1, there are substantial variations in average values of these variables.

The observed average GDP per capita ranges from the lowest $\$ 895.7$ in the Congo Democratic Republic to the highest in Gabon $\$ 15,175.9$. The highest average Gross Fixed Capital Accumulation (GFCA) for sixteen years is 35.7 (\% of GDP) which is observed in Ethiopia, with the lowest being about 9 (\% of GDP) in Zimbabwe. Trade openness which is the ration of the sum of export and import to GDP was highest for Congo, Republic (0.95) implying heavy dependence on international trade, with the lowest average value seen in Sudan (0.26). Finally, the data obtained from the World Bank dataset have also revealed that the Congo Republic enjoyed the highest foreign direct investment (16.3\% of GDP) followed by Mozambique (15.5\% of GDP).

Similarly, the sixteen years of the average value of individual governance indicators and the composite index for the 22 SSA countries are presented in Annex 2. As shown in the annex table, based on the composite governance index (CGI), eleven countries (Botswana, Burkina Faso, Ethiopian, Ghana, Malawi, Mozambique, Namibia, Senegal, South Africa, Tanzania, and Zimbabwe) registered positive average composite governance index. Similarly, Congo, Democratic Republic, Zambia, and Angola registered poor performance in Composite Governance Index during the same year. The table also indicates that there are significant variations in the average value of each governance indicators. Three countries namely, Burkina Faso, Mozambique, and South Africa (South Africa except for Political Stability) registered positive average value of the estimates on all of the six governance indicators during the last 16 years.

The issue of political stability is a more serious problem in countries such as Sudan, Congo Democratic Republic, Nigeria, and Ethiopia. Similarly, the problem of proper implementation of the rule of law in Zambia, Congo Democratic Republic, Sudan, and Angola deserves serious attention. Moreover, the problem of regulatory 
quality in Zimbabwe, voice, and accountability in Sudan, government effectiveness problems in the Congo Democratic Republic are the highest average values observed among the 22 SSA countries under the study period. Table 1 below shows the result of the principal component analysis that helps to form a composite governance index. As shown on the table the eigenvalue responding to the first-factor loading $\left(\mathrm{Comp}_{1}\right)$ is the highest (5.2) and is also greater than 1 , while the rest of the factor loadings having eigenvalue less than 1 .

Table 1: Result of Principal Component Analysis (PCA)

\begin{tabular}{lllllll}
\hline & \multicolumn{7}{c}{ Factor loadings } \\
\hline Governance Indicators & Comp1 & Comp2 & Comp 3 & Comp4 & Comp5 & Comp6 \\
\hline Corruption (CR) & $\mathbf{0 . 4 1 7 7}$ & 0.0349 & -0.6974 & -0.2600 & 0.3406 & -0.3929 \\
Government Effectiveness (GE) & $\mathbf{0 . 4 1 9 8}$ & -0.2657 & -0.1890 & 0.3230 & 0.2339 & 0.7473 \\
Political Stability (PS) & $\mathbf{0 . 3 5 6 5}$ & 0.8821 & 0.2427 & 0.0830 & 0.1419 & 0.0945 \\
Regulatory Quality (RQ) & $\mathbf{0 . 4 1 0 9}$ & -0.3470 & 0.5330 & 0.3191 & 0.3339 & -0.4618 \\
Rule of Law (RL) & $\mathbf{0 . 4 2 4 2}$ & -0.0074 & -0.1674 & 0.3260 & -0.8103 & -0.1706 \\
Voice and Accountability (VA) & $\mathbf{0 . 4 1 6 3}$ & -0.1722 & 0.3269 & -0.7830 & -0.2029 & 0.1894 \\
\hline Eigenvalue & 5.15948 & .427664 & .146364 & .116622 & .0806121 & .0692591 \\
Proportion variance & $\mathbf{0 . 8 5 9 9}$ & 0.0713 & 0.0244 & 0.0194 & 0.0134 & 0.0115 \\
Cumulative variance & 0.8599 & 0.9312 & 0.9556 & 0.9750 & 0.9885 & 1.0000 \\
\hline
\end{tabular}

This shows that all indicators can better be summarized and explained by the first-factor loading. Therefore, the first factor with an eigenvalue of 5.2 can explain about $86 \%$ of the variation in the composite governance index and thus is used to arrive at the Composite Governance Index (CGI).

\subsection{Econometric Result}

Table 2 below shows the empirical result of GMM estimation using aggregate composite governance index and all control variables. As shown in the table, the regression coefficient for composite governance index is positive and statistically significant indicating that governance quality has positive impact on economic growth in SSA countries. An average contribution of governance on GDP is 0.034 indicating that in SSA countries, 1 point improvement in composite governance index raises GDP by about 3.4 percent. Even if the there are differences in magnitudes this empirical findings are consistent with the works of (Saima et.al, 2014; Abdullahi et.al, 2019; Salawu, et.al, 2108).

The lagged value of GDP in Log form is also included as an explanatory variable to observe the effect of the previous economic growth on the current growth performance. Luckily, the coefficient of the lagged dependent variable (used as regressor) is positive and statistically significant at $1 \%$ indicating that the model is dynamic. This implies that the system GMM is more suitable as compared to other forms of dynamic estimation techniques.

Table 2:- Dynamic GMM Estimation Result

Dependent Variable - Log GDP per Capita at constant PPP

\begin{tabular}{lccc}
\hline Variable & Coefficient & $\mathbf{z}$ & $\mathbf{p}>/ \mathbf{z} /$ \\
\hline Lagged Log GDP & 0.8295 & 13.25 & 0.000 \\
Foreign Direct Investment & 0.0110 & 2.72 & 0.007 \\
Gross Fixed Capital Formation & -0.0031 & -1.25 & 0.210 \\
Openness & 0.0721 & 2.85 & 0.004 \\
Inflation & -0.0113 & -2.07 & 0.035 \\
School Enrollment & 0.0023 & 0.83 & 0.408 \\
Working Age Population & 0.8710 & 1.31 & 0.190 \\
Composite Governance Index & 0.0337 & 2.64 & 0.008 \\
\hline
\end{tabular}

Note: Lagged Log GDP is the lagged value Log of GDP per capita in PPP

Foreign direct investment, inflation and openness do have statistically significant effect on growth and thus found to be consistent with previous empirical works and theoretical expectations. The finding reveals that an increase in both trade (openness) and foreign direct investment increases GDP growth per capita, whereas higher inflation reduces economic growth performance. However, gross fixed capital formation, percentage of working age population and school enrollment (a proxy for education) are not statistically significant at influencing growth.

The disaggregated GMM estimation result for individual governance indicators is also provided in Table 3. The result helps us to observe the effect of each governance indicator on economic growth. Since, the individual governance indicators are highly collinear, use of all of them at the same time will lead to the problem of multicollinearity. Therefore, different specifications are estimated by using only one governance indicator at a time, together with the control variables each time. As can be seen in the table, all governance indicators except regulatory quality are statistically significant with; corruption and political stability having negative significant effect on growth and the rest positive. 
Table 3- Disaggregated effect of governance indicators on economic growth (GMM Estimation)

\begin{tabular}{|c|c|c|c|c|c|c|}
\hline Variables & $\begin{array}{l}\text { Equation } \\
1\end{array}$ & $\begin{array}{l}\text { Equation } \\
2\end{array}$ & $\begin{array}{l}\text { Equation } \\
3\end{array}$ & $\begin{array}{l}\text { Equation } \\
4\end{array}$ & $\begin{array}{l}\text { Equation } \\
5\end{array}$ & $\begin{array}{l}\text { Equation } \\
6\end{array}$ \\
\hline Lagged Log GDP & $\begin{array}{l}0.859 \\
(22.7)^{* * *}\end{array}$ & $\begin{array}{l}0.823 \\
(12.4)^{* * *}\end{array}$ & $\begin{array}{l}0.819 \\
(11.70) * * *\end{array}$ & $\begin{array}{l}0.882 \\
(10.9)^{* * *}\end{array}$ & $\begin{array}{l}0.816 \\
(8.0)^{* * *}\end{array}$ & $\begin{array}{l}0.813 \\
(8.5)^{* * *}\end{array}$ \\
\hline Foreign Direct Investment & $\begin{array}{l}0.001 \\
(2.4)^{* *}\end{array}$ & $\begin{array}{l}0.008 \\
(2.3)^{* *}\end{array}$ & $\begin{array}{l}0.009 \\
(2.94)^{* * *}\end{array}$ & $\begin{array}{l}0.005 \\
(1.52)\end{array}$ & $\begin{array}{l}0.007 \\
(2.89)^{* * *}\end{array}$ & $\begin{array}{l}0.001 \\
(2.80)^{* * *}\end{array}$ \\
\hline $\begin{array}{l}\text { Gross Fixed } \quad \text { Capital } \\
\text { Formation }\end{array}$ & $\begin{array}{l}-0.002 \\
(-0.77)\end{array}$ & $\begin{array}{l}-0.004 \\
(-1.51)\end{array}$ & $\begin{array}{l}-0.0017 \\
(-0.74)\end{array}$ & $\begin{array}{l}-0.005 \\
(-1.81)^{*}\end{array}$ & $\begin{array}{l}-0.004 \\
(-1.33)\end{array}$ & $\begin{array}{l}0.0004 \\
(0.46)\end{array}$ \\
\hline Openness & $\begin{array}{l}0.076 \\
(2.83)^{* * *}\end{array}$ & $\begin{array}{l}0.071 \\
(3.12)^{* * *}\end{array}$ & $\begin{array}{l}0.070 \\
(3.14)^{* * *}\end{array}$ & $\begin{array}{l}0.049 \\
(1.94)^{*}\end{array}$ & $\begin{array}{l}0.064 \\
(2.07)^{* *}\end{array}$ & $\begin{array}{c}0.063 \\
(2.27)^{* *}\end{array}$ \\
\hline Inflation & $\begin{array}{l}-0.001 \\
(-0.32)\end{array}$ & $\begin{array}{l}-0.002 \\
(-0.78)\end{array}$ & $\begin{array}{l}-0.0016 \\
(-0.58)\end{array}$ & $\begin{array}{l}-0.0001 \\
(-0.03)\end{array}$ & $\begin{array}{l}-0.0001 \\
(-0.25)\end{array}$ & $\begin{array}{l}-0.000 \\
(-0.21)\end{array}$ \\
\hline School Enrollment & $\begin{array}{l}0.0003 \\
(-0.32)\end{array}$ & $\begin{array}{l}0.003 \\
(0.92)\end{array}$ & $\begin{array}{l}0.002 \\
(0.76)\end{array}$ & $\begin{array}{l}0.003 \\
(1.11)\end{array}$ & $\begin{array}{l}0.0008 \\
(1.38)\end{array}$ & $\begin{array}{l}0.0007 \\
(1.24)\end{array}$ \\
\hline Working Age Population & $\begin{array}{l}0.917 \\
(1.40)\end{array}$ & $\begin{array}{l}0.964 \\
(1.78)^{*}\end{array}$ & $\begin{array}{l}0.930 \\
(1.36)\end{array}$ & $\begin{array}{l}0.498 \\
(0.82)\end{array}$ & $\begin{array}{l}0.873 \\
(0.96)\end{array}$ & $\begin{array}{l}0.859 \\
(0.95)\end{array}$ \\
\hline Corruption & $\begin{array}{l}-0.044 \\
(-2.55) * * *\end{array}$ & & & & & \\
\hline Government Effectiveness & & $\begin{array}{l}0.058 \\
(2.52)^{* *}\end{array}$ & & & & \\
\hline Political Stability & & & $\begin{array}{l}-0.024 \\
(-1.97)^{* *}\end{array}$ & & & \\
\hline Regulatory Quality & & & & $\begin{array}{l}0.037 \\
(1.71)\end{array}$ & & \\
\hline Rule of Law & & & & & $\begin{array}{l}0.044 \\
(2.09)^{* *}\end{array}$ & \\
\hline Voice and Accountability & & & & & & $\begin{array}{l}0.040 \\
(1.99)^{* *}\end{array}$ \\
\hline
\end{tabular}

Note from the table that $* * * * *$, and $*$ are 1,5 , and 10 percent levels of significance respectively.

Z-statistics in the bracket

The result reveals that weak corruption control and problems of political stability reduce GDP growth by about 4.4 percent and 2.4 percent respectively. The government effectiveness has strong positive effect on growth performance, where a unit improvement in government effectiveness index will lead to 5.8 percent increase in GDP. Similarly, a unit improvement in the index of rule of law and voice and accountability will lead to an increase in GDP by 4.4 and 4 percent respectively. These findings are consistent with the findings of many empirical studies (Abdullahi et.al., 2019; Juzhong et.al., 2010; Salawu, 2018; Han et.al., 2014; Noha and I-Ming, 2016; Saima et.al., 2014).

\section{Summary, Conclusions and Policy Implications}

The paper examined the effect of governance quality on growth performance of Sub-Saharan Africa Countries based on a panel data obtained from the World Bank dataset. The research problem was examined using the dynamic panel systems GMM on selected 22 countries over the period of 2002 to 2018 . The result confirmed that overall governance indicator (aggregate or composite governance index) has a positive and significant impact on economic growth of Sub-Saharan Africa Countries, implying that an improvement in governance indicators or governance quality plays important role at influencing economic growth of these countries.

The disaggregated result has also revealed that corruption and political stability are both negative and statistically significant at influencing economic growth performance reflecting the existing situations in the region that the problems of corruption control as well as political stability need to be addressed for better economic growth. Moreover, even if government effectiveness, rule of law and voice and accountability has varying magnitudes, they portray positive and statistically significant effect on economic growth of the countries. All in all, governance quality be it at aggregate or disaggregate form play crucial role in economic growth of developing sub -Saharan Africa counties. Moreover, the control variables related to foreign capital in-flow such as foreign direct investment and trade openness play significant role in economic growth performance of these countries.

Thus, efforts and strong policy interventions to control corruption and political instability as well as government's effort to encourage popular participation in selecting governments along with freedom of expression, freedom of association, and a free media are important to promote economic growth in these countries. Besides, improving the quality of the civil service and the degree of its independence from political pressures together with the quality of policy formulation and implementation, and encouraging the measures taken to promote property 
right ownership are crucially necessary to promoting better growth performance. Moreover, those measures that promote more efficient in-flow of capital in terms of foreign direct investment and trade interactions are paramount important. Finally, as this paper did not capture the causality relationship from growth to improvement of governance, future researches may work on this to confirm the reverse situation, that is, whether higher growth performance can induce governance quality or not.

\section{References}

Abdullahi, S., Rusmawati, S., Normaz, W. \& Nur, S. M. (2019). Public Debt, Institutional Quality, and Economic Growth in Sub-Saharan Africa. Institutions and Economies, 11(3), 39-64.

Acemoglu, D. \& J. Robinson (2005b). Institutions as the Fundamental Cause of Long-Run Growth. In Philippe Aghion and Steve Durlauf, eds., Handbook of Economic Growth. P. 386-472.

Acemoglu, D., Johnson, S. \& Robinson, J. (2001). the Colonial Origins of Comparative Development: An Empirical Investigation. American Economic Review, 91 (5), 1369-1401.

Albassam, B. (2013). The Relationship between Governance and Economic Growth During Times of Crisis. European Journal of Sustainable Development, 2(4), 1-18.

(2012a). The Influence of the Economic Crisis on the Relationship between Governance and Economic Growth. (Doctoral dissertation); Florida Atlantic University, Boca Raton, FL, USA.

Alkire, S. (2010). Human Development: Definitions, Critiques, and Related Concepts. Human Development Reports (Research Paper 2010/01).

Arellano, M. and Bond, S. (1991). Some Tests of Specification for Panel Carlo Evidence and an Application to Employment Equations. The Economic Studies, 58(2), 277-297.

Asongu, S., Batuo, M. and Mlambo, K. (20128). Linkages between Financial Development, Financial Instability, Financial Liberalisation and Economic Growth in Africa: Research in International Business and Finance, 45(October), 168-179.

Azmat,G. (2011). Governance and Growth in Developing Countries: Journal of Economic Issues, 45(1), $19-39$.

Baltagi, H., Demetriades, P. O. and Law, S. H. (2008). Financial Development and Openness: Evidence from Panel Data. Center for Policy Research. 60. Retrieved from https://surface.syr.edu/cpr/60.

Blundell, R.W. and Bond, S.R. (1998) Initial Conditions and Moment Restrictions in Dynamic Panel Data Models, Journal of Econometrics, 87(1),115-143.

Commission on Global Governance (ed.). 1995. Our global neighbourhood, 2-3. Oxford: Oxford University Press.

de Ferranti, D. M., Jacinto, J., Ody, A., \& Ramshaw, G. (2009). How to Improve Governance: A New Framework for Analysis and Action. Washington, D.C: Brookings Institution Press.

Dixit, A. (2009) Governance Institutions and Economic Activity." American Economic Review, 99 (1),5-24.

Arndt, C. and Oman, C. (2010). Measuring Governance; Policy Brief No. 39 OECD Development Center; 75775 Paris Cedex 16, France.

Furubotn, E. G. \& Richter, R. (2005). Institutions and Economic Theory: the Contribution of the New Institutional Economics (2nd ed.). Ann Arbor, Michigan: University of Michigan Press.

Han, X., Khan, H., and Zhuang, J. (2014). Do Governance Indicators Explain Development Performance? A CrossCountry Analysis. ADB Economics Working Paper Series. No 417.

Juzhong, Z., Emmanuel, de D. and Anneli, Lagman-Martin (2010). Governance and Institutional Quality and the Links with Economic Growth and Income Inequality: With Special Reference Developing Asia. ADB Economics Working Paper Series No. 193.

Kaufmann, D., Kraay, A., \& Mastruzzi, M. (2009). Governance Matters VIII: Aggregate and Individual Governance Indicators, 1996-2008. World Bank Policy Research Working Paper No. 4978.

(2010). The Worldwide Governance Indicators: Methodology and Analytical Issues (World Bank Policy Research Working Paper No. 5430).Washington, DC: The World Bank.

(2003). Governance Matters III. Governance Indicators for 1996-2002. World Bank Policy Research Department, Washington, DC.

Kaufmann, D., and A. Kraay (2008). Governance Indicators: Where Are We, Where Should We Be Going? World Bank Research Working Paper No. 4370, Washington, DC.

.(2002) Growth without Governance [with Comments]. Economía, 3(1), 169- 229.

Noha, E. and I-Ming, C. (2016). The Impact of Governance on Economic Growth: The Case of Middle Eastern and

North African Countries. Topics in Middle Eastern and African Economies, 18(1), 126- 144.

OECD (1995). Participatory Development and Good Governance. Development Co-operation Series, Head of Publication Service 75775, Paris, CEDEX, France.

Quibria, M. G.(2006). Does Governance Matter? Yes, No or Maybe: Some Evidence from Developing Asia. (2006). 1-26. Research Collection School of Economics. Available at: https://ink.library.smu.edu.sg/soe_research/866. 
Raj, N. and Breda, G. (2011). Understanding Growth and Poverty: Theory, Policy, and Empirics. The International Bank for Reconstruction and Development / the World Bank, 1818 H Street NW, Washington DC 20433.

Rasha, O., Constantinos, A. and Persefoni, T. (2011). The role of institutions in economic development: Evidence from 27 Sub-Saharan African countries. International Journal of Social Economics, 39(1), 142 -160.

Robert, E. L. (1988). On the Mechanics of Economic Development. Journal of Monetary Economics, 22 (1988), 3-42.

Romer, P. M. (1986). Increasing Returns and Long Run Growth. Journal of Political Economy, 94(5),1002-1037. (1990). Increasing Returns and Long Run Growth. Journal of Political Economy, 98(5), S71-S102.

Saima, N., Nasir, I. and Muhammad, A. K. (2014). The Impact of Institutional Quality on Economic Growth: Panel Evidence. Pakistan Development Review, 53 (1),15-31.

Salawu, M.B., Yusuff, A.S., Salman, K.K., Ogunniyi, A.I. and A.M Rufa (2018). Does Governance Influence Economic Growth in Sub-Saharan Africa? Global Journal of Human-Social Science: Economics; 18(1).

Sied, M. J, (2017).The relationship between governance and economic growth. International Journal of Current Research, 9(9), 57451-57457.

Solow, R. (1956). A Contribution to the Theory of Economic Growth." Quarterly Journal of Economics, $70(1), 65-94$.

Thomas, M. (2008). What do the worldwide governance indicators measure? Retrieved from http://www.saisjhu.edu/bin/q/r/.

United Nations Development Programme (UNDP) (1997). Governance for Sustainable Human Development. New York: UNDP.

World Bank (2018). World Governance Indicators online; accessible at: http://data.worldbank.org/ Datacatalog/ worldwide-governance-indicators. (2007a). Strengthening the World Bank Group Engagement on Governance and Anticorruption?' Strategic Document, March. Washington DC.

(2007b). A Decade of Measuring the Quality of Governance: Governance Matters 2007'. Worldwide Governance Indicators, 1996-2006. Washington DC: International Bank for Reconstruction and Development/World Bank.

Yu, K. (2017). Governance and Good Governance: A New Framework for Political Analysis. Fudan Journal of Human Soc. Sci., (11)18, 1-8.

Annex 1:- Average value of the dependent variable and control variables for 22 countries (16 years average

\begin{tabular}{lrrrrrr}
\hline \multicolumn{1}{c}{ Country } & \multicolumn{1}{c}{ GDP } & FCA & POPU. & OPEN & \multicolumn{1}{c}{ EDUC. } & FDI \\
\hline Angola & $7,129.6$ & 27.5 & 50.6 & 0.86 & 107.5 & 1.56 \\
Botswana & $14,735.9$ & 30.5 & 60.9 & 0.89 & 107.6 & 3.05 \\
Burkina Faso & $1,736.9$ & 18.9 & 51.4 & 0.39 & 75.0 & 1.28 \\
Cameroon & $3,181.8$ & 22.8 & 53.4 & 0.46 & 107.4 & 1.82 \\
Congo, Dem. Rep. & 895.7 & 18.1 & 50.9 & 0.64 & 99.8 & 4.78 \\
Congo, Rep. & $3,421.3$ & 25.0 & 55.5 & 0.95 & 108.5 & 16.29 \\
Cote d'Ivoire & $3,956.4$ & 13.9 & 53.8 & 0.66 & 80.9 & 1.53 \\
Ethiopia & $1,315.4$ & 35.7 & 52.3 & 0.45 & 89.5 & 2.95 \\
Gabon & $15,175.9$ & 26.1 & 57.9 & 0.57 & 139.7 & 4.31 \\
Ghana & $3,914.4$ & 21.4 & 57.6 & 0.68 & 97.6 & 5.38 \\
Kenya & $3,400.4$ & 19.1 & 55.1 & 0.46 & 102.6 & 1.09 \\
Malawi & 917.2 & 14.5 & 51.4 & 0.46 & 138.8 & 3.52 \\
Mozambique & $1,032.9$ & 21.3 & 51.6 & 0.72 & 104.9 & 15.53 \\
Namibia & $8,946.2$ & 23.7 & 58.1 & 0.73 & 117.8 & 5.32 \\
Nigeria & $4,682.8$ & 19.5 & 53.1 & 0.33 & 92.6 & 1.65 \\
Senegal & $2,784.4$ & 22.6 & 53.2 & 0.52 & 82.5 & 2.05 \\
South Africa & $12,190.7$ & 19.1 & 65.1 & 0.48 & 104.6 & 1.38 \\
Sudan & $3,470.7$ & 20.5 & 54.1 & 0.26 & 69.8 & 3.94 \\
Tanzania & $2,033.7$ & 31.0 & 52.7 & 0.41 & 97.4 & 3.25 \\
Uganda & $1,801.2$ & 23.1 & 49.2 & 0.31 & 118.1 & 3.69 \\
Zambia & $2,945.6$ & 29.3 & 51.2 & 0.60 & 104.1 & 5.76 \\
Zimbabwe & $2,610.5$ & 8.9 & 55.1 & 0.42 & 110.6 & 1.44 \\
\hline Source own & & & & & &
\end{tabular}

Source own computation 
Annex 2: Sixteen years of average governance indicators for 22 SSA Countries

\begin{tabular}{|c|c|c|c|c|c|c|c|}
\hline Country & $\mathrm{CC}$ & GE & PS & $\mathbf{R Q}$ & RL & VA & CGI \\
\hline Angola & -1.32 & -1.13 & -0.57 & -1.09 & -1.28 & -1.16 & -1.10 \\
\hline Botswana & -0.26 & -0.60 & -0.35 & -0.27 & -0.44 & -0.25 & 0.81 \\
\hline Burkina Faso & 0.94 & 0.51 & 1.02 & 0.56 & 0.62 & 0.51 & 2.16 \\
\hline Cameroon & -1.12 & -0.83 & -0.67 & -0.84 & -1.09 & -1.03 & -0.81 \\
\hline Congo, Dem. Rep. & -1.38 & -1.61 & -2.16 & -1.44 & -1.63 & -1.44 & -1.17 \\
\hline Congo, Rep. & -1.15 & -1.19 & -0.69 & -1.23 & -1.19 & -1.09 & -0.85 \\
\hline Cote d'Ivoire & -0.87 & -1.01 & -1.47 & -0.71 & -1.10 & -0.87 & -0.37 \\
\hline Ethiopia & -0.60 & -0.61 & -1.54 & -1.03 & -0.68 & -1.28 & 0.09 \\
\hline Gabon & -0.81 & -0.75 & 0.19 & -0.55 & -0.54 & -0.86 & -0.31 \\
\hline Ghana & -0.14 & -0.09 & 0.02 & -0.08 & 0.03 & 0.41 & 1.04 \\
\hline Kenya & -0.96 & -0.51 & -1.24 & -0.24 & -0.75 & -0.26 & -0.60 \\
\hline Malawi & -0.63 & -0.62 & -0.02 & -0.61 & -0.23 & -0.24 & 0.04 \\
\hline Mozambique & 0.30 & 0.13 & 0.76 & 0.07 & 0.19 & 0.41 & 1.59 \\
\hline Namibia & -0.61 & -0.63 & -0.02 & -0.51 & -0.72 & -0.19 & 0.09 \\
\hline Nigeria & -1.15 & -1.03 & -1.94 & -0.89 & -1.14 & -0.64 & -0.86 \\
\hline Senegal & -0.21 & -0.35 & -0.18 & -0.21 & -0.19 & 0.08 & 0.87 \\
\hline South Africa & 0.17 & 0.45 & -0.11 & 0.45 & 0.11 & 0.63 & 1.47 \\
\hline Sudan & -1.34 & -1.35 & -2.19 & -1.39 & -1.33 & -1.73 & -1.09 \\
\hline Tanzania & -0.56 & -0.55 & -0.35 & -0.45 & -0.41 & -0.25 & 0.19 \\
\hline Uganda & -0.93 & -0.52 & -1.00 & -0.19 & -0.40 & -0.59 & -0.54 \\
\hline Zambia & -1.33 & -1.25 & -0.96 & -1.93 & -1.63 & -1.41 & -1.12 \\
\hline Zimbabwe & -0.476 & -0.701 & 0.286 & -0.512 & -0.393 & -0.248 & 0.374 \\
\hline
\end{tabular}

Note: $\mathrm{CR}=$ Corruption Control, $\mathrm{GE}=$ Government Effectiveness, $\mathrm{PS}=$ Political Stability, $\mathrm{RQ}=$ Regulatory Quality, $\mathrm{RL}=$ Rule of Law, $\mathrm{VA}=$ Voice and Accountability and $\mathrm{CGI}=$ Composite Governance Index

Annex 3: Descriptive Statistics

\begin{tabular}{llllll}
\hline \multicolumn{1}{c}{ Variable } & Obser. & Mean & Std. Dev. & Min. & Max. \\
\hline GDP Per Capita Constant PPP adjusted & 374 & 4649.07 & 4258.58 & 715.46 & 17634.14 \\
Foreign Direct Investment (\% of GDP) & 374 & 4.16 & 6.14 & -6.37 & 49.99 \\
Fixed Capital Accumulation (\% of GDP) & 374 & 22.39 & 7.59 & 2.01 & 42.79 \\
Inflation & 374 & 10.21 & 16.74 & -29.69 & 196.9 \\
The working-age population (in \%) & 374 & 54.29 & 3.79 & 48.05 & 65.70 \\
Trade Openness (Export+Import/GDP) & 374 & 0.56 & 0.30 & 0.00 & 1.57 \\
Gross Primary School Enrollment & 374 & 102.62 & 18.76 & 47.06 & 147.39 \\
Composite Governance Index & 374 & $1.53 \mathrm{e}-09$ & 1.002 & -1.348 & 2.488 \\
\hline
\end{tabular}

Annex 4: Correlation Matrix

\begin{tabular}{llllllll}
\hline & GDP & FDI & CAPITAL & POPULATION & OPENNESS & SCHOOL & CGI \\
\hline GDP & 1.0000 & & & & & & \\
FDI & 0.0173 & 1.0000 & & & & & \\
CAPITAL & 0.2233 & 0.2106 & 1.0000 & & & & \\
POPULATION & 0.1617 & 0.1045 & 0.2803 & 1.0000 & & & \\
OPENNESS & 0.1666 & 0.2134 & 0.3193 & 0.1154 & 1.0000 & & \\
SCHOOL & -0.1088 & 0.1371 & 0.0608 & 0.0180 & 0.2471 & 1.0000 & 1.0000 \\
CGI & 0.0097 & -0.0100 & -0.1075 & -0.2692 & -0.0123 & 0.0406 & \\
\hline
\end{tabular}

